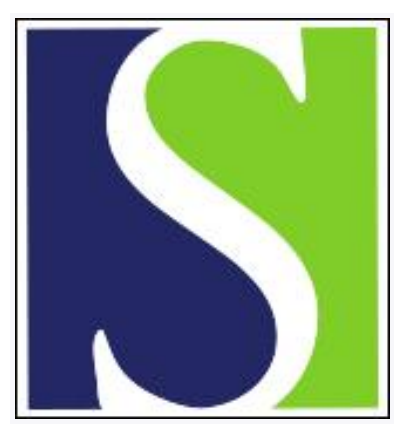

Scand J Work Environ Health 1979;5(4):362-367

https://doi.org/10.5271/sjweh.2645

Issue date: Dec 1979

Serum and urinary vanadium of vanadium-exposed workers.

by Kiviluoto M, Pyy L, Pakarinen A

Key terms: exposure; serum vanadium; urinary vanadium; vanadium; vanadium dust; vanadium excretion; vanadium exposure; vanadium-exposed worker; worker

This article in PubMed: www.ncbi.nlm.nih.gov/pubmed/538427

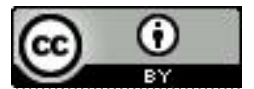




\title{
Serum and urinary vanadium of vanadium-exposed workers
}

\author{
by MARKKU KIVILUOTO, M.D.,1 LAURI PYY, M.Sc., ${ }^{2}$ and ARTO PAKARINEN, \\ M.D. ${ }^{3}$
}

\begin{abstract}
KIVILUOTO, M., PYY, L. and PAKARINEN, A. Serum and urinary vanadium of vanadium-exposed workers. Scand. j. work environ. \& health 5 (1979) 362-367. In this investigation the environment of vanadium workers was studied. It was found that low concentrations of vanadium $\left(0.01-0.04 \mathrm{mg} / \mathrm{m}^{3}\right)$ in the air do not correlate with vanadium serum levels or its urinary excretion. The results, however, suggest that values of vanadium in serum and urine samples reflect absorption of vanadium because vanadium could not be detected in the urire of referents. In higher vanadium exposure $\left(0.2-0.5 \mathrm{mg} / \mathrm{m}^{3}\right)$, the concentration in the air inhaled remaining unknown due to the use of dust masks, urinary vanadium excretion and serum vanadium level decreased significantly with exposure-free time.
\end{abstract}

Key words: serum vanadium, urinary vanadium, vanadium, vanadium dust, vanadium excretion, vanadium exposure.

Vanadium is used in the steel industry as an alloy substance to improve the properties of steel, as well as in the chemical industry as a catalyst. Exposure to vanadium is possible during the various stages of its separation, in the steel industry, and in certain branches of the chemical industry. It may also occur when oil- or gas-fired boilers are being cleaned or repaired (2, 19) because some oils and gases contain vanadium.

Vanadium enters the body mainly through the lungs; it is excreted in the urine and, to a minor degree, in feces (3,

1 Health Center of Otanmäki Mine of Rautaruukki Company, Otanmäki, Finland.

2 OuIu Regional Institute of Occupational Health, Oulu, Finland.

3 Department of Clinical Chemistry, University of Oulu, Oulu, Finland.

Reprint requests to: Mr. Lauri Pyy, Oulu Regional Institute of Occupational Health, Box 451, SF-90101 Oulu 10, Finland.
14). The injurious effects of vanadium have been described elsewhere $(3,8,9)$.

This study was undertaken in the vanadium factory of the Otanmäki Mine of the Rautaruukki Company, Finland, which has been manufacturing vanadium since 1956 . The annual output of the factory is up to 2,400 tons. During the process, magnetite is roasted with sodium carbonate into pellets. The roasted product is leached, and vana. dium is precipitated from the leach liquor as vanadates.

The "red cake" thus produced is filtered, washed, and smelted into vanadium pentoxide. Controlling vanadium dust has been very difficult at the smelting furnaces and during the packing of the vanadium pentoxide smelt, the processing of the filtered precipitate, and the grinding of laboratory samples.

The concentration of vanadium in the factory air has been measured occasionally in the past. A summary of the previous 
measurements is given in table 1 . There it can be seen that in the dustiest work areas the total concentration of vanadium in the air exceeded or was equal to the threshold limit value (TLV) of $0.5 \mathrm{mg} / \mathrm{m}^{3}$ (1). The vanadium concentrations have been determined from the total dust collected during $1-3 \mathrm{~h}$. The urinary vanadium concentrations of the exposed workers had been, in many cases, higher than recommended by the Institute of Occupational Health in Finland $(0.6 \mu \mathrm{mol} / \mathrm{l})$. Therefore thorough measurements of vanadium exposure and determinations of serum and urinary vanadium were undertaken.

\section{MATERIAL AND METHODS}

\section{Subjects}

The subjects of the study were process workers, dayworkers, repairmen, foremen, and a laboratory worker, 60 men in all. The normal urinary vanadium excretion was measured from 24 referents unexposed to vanadium.

\section{Dust sampling}

The concentrations of vanadium in the factory air were determined by measurements covering two shifts just before the biological sampling in March-May 1976. The number of samples taken from the breathing zones was 112, and that of the stationary samples 80 . The samples were taken by methods commonly used by the Institute of Occupational Health in Finland $(15,16)$.

\section{Biological sampling}

In order to determine the excretion rate of vanadium, we measured vanadium from successive blood and 18- to 24-h urine samples (8 men) in December 1975. The first blood samples were taken just before the workers left the factory for $3 \mathrm{~d}$ of rest. The second and third blood samples were taken 18 and $42 \mathrm{~h}$ after they had left the factory. The urine samples were taken $0-18,18$ 42 and $42-66 \mathrm{~h}$ after the beginning of the 3 -d rest period.

The serum vanadium levels of all the workers exposed to vanadium $(60 \mathrm{men})$ were examined in March-May 1976 at the end of a work shift. At the same time the urine collections for the next $18 \mathrm{~h}$ were started to determine the amount of excreted vanadium. In August 1978 we determined the urinary vanadium excretion of the reference group.

\section{Analysis of vanadium}

The Millipore filters (type AAWP 03700, pore size $0.8 \mu \mathrm{m}$ ) on which the dust samples were collected were wet ashed with a mixture of nitric acid and hydrochloric acid. The rest was dissolved in $5 \%$ nitric acid. The vanadium concentrations were determined with an atomic absorption spectrophotometer with a flameless graphite atomizer (Perkin-Elmer 300, HGA 74).

Table 1. Previous total vanadium concentrations in the air $\left(\mathrm{mg} / \mathrm{m}^{3}\right)$.

\begin{tabular}{|c|c|c|c|c|c|c|c|c|}
\hline \multirow[b]{2}{*}{ Site or job } & \multicolumn{8}{|c|}{ Time of measurement } \\
\hline & $\begin{array}{l}\text { Jan. } \\
1957\end{array}$ & $\begin{array}{c}\text { March } \\
1970\end{array}$ & $\begin{array}{l}\text { Feb. } \\
1972\end{array}$ & $\begin{array}{c}\text { April } \\
1972\end{array}$ & $\begin{array}{l}\text { May } \\
1972\end{array}$ & $\begin{array}{l}\text { Oct. } \\
1973\end{array}$ & $\begin{array}{c}\text { March } \\
1974\end{array}$ & $\begin{array}{l}\text { May } \\
1975\end{array}$ \\
\hline Sintering furnaces (discharge) & 0.1 & 0.1 & 0.0 & & & & & \\
\hline Packing of smelt & 3.9 & 0.9 & 0.2 & 0.2 & 0.05 & 0.1 & 0.1 & 0.6 \\
\hline Smelt furnaces & & 1.9 & 0.5 & 0.2 & 0.8 & & 1.0 & \\
\hline Packing of precipitate & 0.0 & 0.1 & 0.3 & & & & 0.3 & \\
\hline Grinding of samples & & & & & $1-10$ & & & \\
\hline Sintering furnaces (charging) & 0.2 & & & & & & & \\
\hline Filtering & & 0.01 & 0.2 & & & 0.2 & & 0.5 \\
\hline Pelleting machine & 0.1 & 0.1 & & & & 0.0 & & \\
\hline
\end{tabular}


The sensitivity of the method was 0.002 mg for $1 \%$ absorption, and the coefficient of variation within runs $6 \%$ at a concentration level of $0.05 \mathrm{mg} / \mathrm{m}^{3}$. The particle size was determined by a modified Andreasen sedimentation method (10) from five dust samples, which were taken separately with a high-volume sampler.

The content of vanadium in the urine and serum of the subjects was determined in the Technical Research Center of Finland with an atomic absorption spectrophotometer with a graphite furnace (Perkin-Elmer 503, HGA 72). The reliability of the method was checked with five duplicate urine and serum samples spiked with $0,0.1,0.2,0.5$ and $1 \mu \mathrm{mol} / \mathrm{l}$.

The range of recovery of standard additions was $70-120 \%$, and the given sensitivity of the method was $0.08 \mu \mathrm{mol} / 1$. The coefficient of variation within runs of the method was $34 \%$ (random) for the urine determination at a concentration level of $0.2 \mu \mathrm{mol} / 1$, and $38 \%$ for the serum determination at the same level.

The urinary vanadium excretion of the referents was determined in the Oulu Regional Institute of Occupational Health (Perkin-Elmer 603, HGA 74). The sensitivity ( $1 \%$ absorption) of the method was $0.04 \mu \mathrm{mol} / 1$, and the coefficient of variation within runs at a concentration level of $0.2 \mu \mathrm{mol} / \mathrm{I}$ (spiked samples) was $20 \%$ (random).

\section{Statistical methods}

The differences in the urinary excretions and serum levels of vanadium were investigated with the Wilcoxon signed-ranks test. The correlation coefficients between the concentrations of vanadium in factory air, serum, and urine were calculated.

Table 2. Total vanadium concentrations in the air $\left(\mathrm{mg} / \mathrm{m}^{3}\right)$.

\begin{tabular}{|c|c|c|c|c|}
\hline Site or job & $\begin{array}{c}\text { No. of } \\
\text { workers } \\
\text { or sites }\end{array}$ & $\begin{array}{c}\text { No. of } \\
\text { samples }\end{array}$ & Range & $\begin{array}{c}\text { Time } \\
\text { weighted } \\
\text { mean con- } \\
\text { centration }\end{array}$ \\
\hline Breathing zone samples covering whole shift & 58 & 112 & $0.002-0.42$ & 0.028 \\
\hline Breathing zone samples at grinding ( $1 \mathrm{~h}$ samples) & 1 & 2 & $0.25-4.7$ & 1.7 \\
\hline Stationary samples covering whole shift & 15 & 80 & $0.002-0.043$ & 0.012 \\
\hline Packing of smelt ( $1 \mathrm{~h}$ samples) & 1 & 7 & $0.020-0.37$ & 0.13 \\
\hline Grinding room & 1 & 1 & 2.3 & 2.3 \\
\hline
\end{tabular}

Table 3. Serum concentration and urinary excretion $(18 \mathrm{~h})$ of vanadium and their correlation with vanadium (V) concentration in the air.

\begin{tabular}{lccc}
\hline Determination & $\begin{array}{c}\text { No. of } \\
\text { samples }\end{array}$ & Mean \pm SD & $\begin{array}{c}\text { Coefficient of } \\
\text { correlation }\end{array}$ \\
\hline Vanadium group & & $0.22 \pm 0.14 \mu \mathrm{mol} / \mathrm{l}$ & $0.04 \pm 0.17 \mu \mathrm{mol}$ \\
Serum vanadium & 60 & & 0.05 \\
Urinary excretion (18 h) & 60 & & 0.07 \\
Serum V vs. total V in breathing zone & 60 & & 0.08 \\
Serum V vs. total V in workroom air & 60 & & 0.04 \\
Urine V vs. total V in breathing zone & 60 & & \\
Urine V vs. total V in workroom air & 60 & not detectable & \\
Urinary V vs. V in serum & & 24 & \\
Reference group &
\end{tabular}

a The sensitivity of the determination method was $0.04 \mu \mathrm{mol} / 1$. 


\section{RESULTS}

\section{Concentration of vanadium in the air}

The concentration of vanadium in the air (table 2) was considerably lower than earlier (table 1). The mean respirable fraction of the dust (particle size $<5 \mu \mathrm{m}$ in diameter) was $20 \%$, and the range of variation $6-32 \%$. Concentrations exceeding the $\mathrm{TLV}, 0.5 \mathrm{mg} / \mathrm{m}^{3}$, were found only during the grinding of laboratory samples. Notable concentrations of vanadium were also found during the packing of smelt. These work periods are very short, and the workers wear dust masks. In the other parts of the factory the vanadium concentration was constantly below 0.1 $\mathrm{mg} / \mathrm{m}^{3}$.

Urinary excretion and serum level of vanadium

The vanadium values of urine collections and successive serum samples taken from eight workers (filter men and workers who packed and smelted) are shown in fig. 1 and 2.

Due to the dust masks no correlation could be determined between the concentration of vanadium in the air and the biological samples. It was found that the excretion of vanadium in urine and the vanadium level of serum decreased significantly with the time the workers spent out of exposure.

The concentration of vanadium in the serum and the urinary excretion of the 60 vanadium workers and the 24 referents were measured. The results can be found in table 3 , along with the correlation coefficients between the vanadium concentration of factory air, serum, and urinary excretion.

\section{DISCUSSION}

In the thorough measurements of the vanadium concentrations in the workroom air and respiratory zones carried out in the vanadium factory, the values measured were $0.01-0.04 \mathrm{mg} / \mathrm{m}^{3}$, which are clearly below the TLV of $0.5 \mathrm{mg} / \mathrm{m}^{3}$. These values are considerably lower than corresponding earlier determinations, probably due to the intensified flushing of the floors of work sites that was started at the beginning of 1976 . The mean urinary $18-\mathrm{h}$ vanadium excretion of the

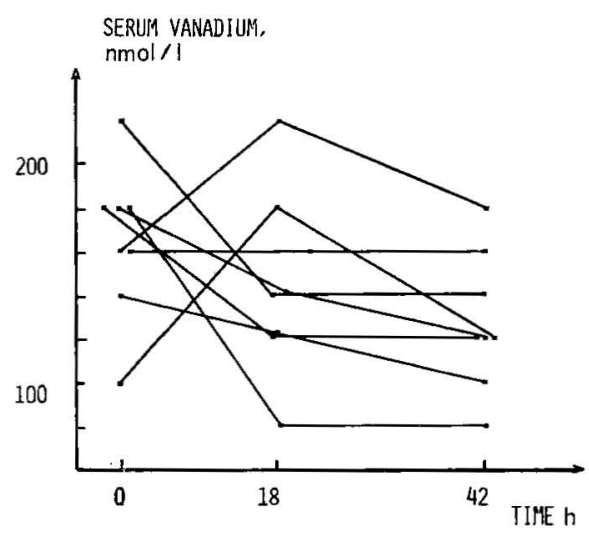

Fig. 1. Urinary excretion pattern of vanadium. (Significance of difiorence between excretions: $42-18 \mathrm{~h}=\mathrm{p}<0.005 ; 66-42 \mathrm{~h}=\mathrm{p}<0.1$; $66-18 \mathrm{~h}=\mathrm{p}<0.025)$

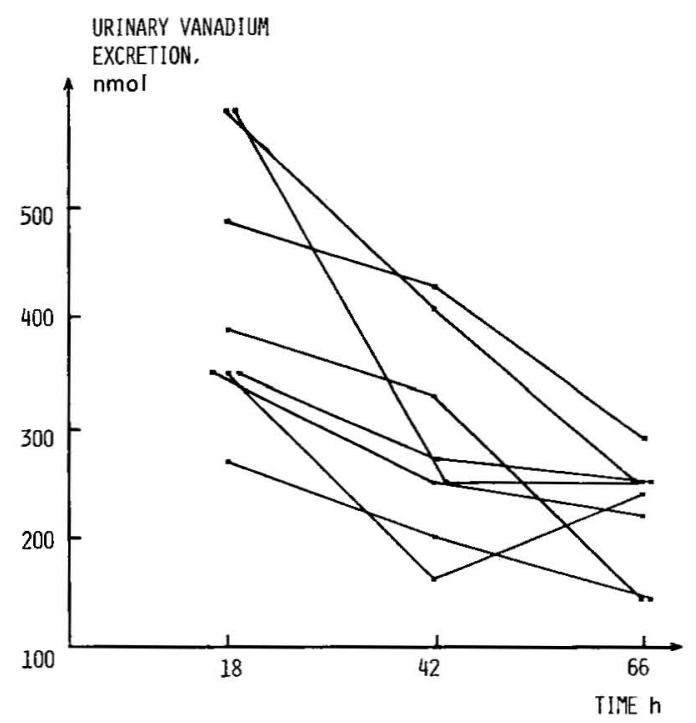

Fig. 2. Serum vanadium levels after exposure. (Significance of difference between levels: $18-0 \mathrm{~h}=\mathrm{p}>0.2 ; 42-18 \mathrm{~h}=\mathrm{p}<0.1$; $42-0 \mathrm{~h}=\mathrm{p}<0.05)$ 
exposed workers was $0.26 \mu \mathrm{mol}$. The concentration of vanadium in the urine of the referents was below $0.04 \mu \mathrm{mol} / 1$, which was the sensitivity of the vanadium assay. Therefore we did not measure the concentration of vanadium in the serum of the referents. The mean vanadium concentration in the serum of the exposed workers was $0.2 \mu \mathrm{mol} / 1$.

Thus our results agree with Sjöberg's figures of lower than $3 \mu \mathrm{g} / 1(0.06 \mu \mathrm{mol} / \mathrm{l})$ for urine and serum (13). On the other hand, for urine, Perry and Perry (11) have reported values of $1-20 \mu \mathrm{g} / 1(0.02-$ $0.4 \mu \mathrm{mol} / 1$ ), and Watanabe et al. (18) 3.5$11.0 \mu \mathrm{g} / 1(0.03-0.2 \mu \mathrm{mol} / \mathrm{l})$. Heydorn and Lukens (4) have given $4.6 \pm 0.8 \mu \mathrm{g} / 1$ $(0.09 \pm 0.016 \mu \mathrm{mol} / \mathrm{l})$ as the normal vanadium level of serum. We found no significant correlation between the vanadium concentration in the factory air and the serum level and the urinary excretion of vanadium.

Jaraczewska and Jakubowski (5) have determined the correlation between the vanadium content of the urine and the vanadium concentration in the workroom air. Neither did they find a statistically significant correlation between the two. Vintinner et al. (17) found an increased urinary vanadium excretion for exposed workers. However, they did not state a correlation coefficient between the vanadium concentration of the inhaled air and urinary vanadium excretion. Roshchin and Ordjonikidze (12) claimed that there is a correlation between vanadium in urine and in the air of work sites, but they did not give the coefficient.

In higher vanadium exposure $(0.2-0.5$ $\mathrm{mg} / \mathrm{m}^{3}$ ) - the vanadium concentration in the air inhaled remaining unknown due the use of dust masks - the urinary vanadium excretion and serum vanadium level decreased significantly with exposure-free time. In the study of Kent and McCance (6) it was found that vanadium was excreted in urine, for the most part, in a week. They administrated vanadium intravenously to two volunteers in their study.

The lack of correlation in our study between a low vanadium concentration $\left(0.01-0.04 \mathrm{mg} / \mathrm{m}^{3}\right)$ in air and serum and the urinary excretion of it could be due to the following reasons: a nonuniform distribution of vanadium dust particle size, interindividual differences in inhalation and absorption even though personal dust sample collection was employed, or analytical problems. The detection limit of the method used was just below the concentration measured, and it explains the high coefficient of variation, which could obscure a possible correlation.

\section{ACKNOWLEDGMENTS}

We wish to thank Ms. A. Laatikainen, Ms. A. Pirnes, Ms. A. Tuura, Mr. O. Juutinen, Mr. K. Kakko, Mr. M. Lindén and Mr. J. Saukkonen for their skillful technical assistance.

We are indebted to the Rautaruukki Company for the possibility of conducting this study. Without the cooperation of both the workers and the management this work would not have been possible.

\section{REFERENCES}

1. AMERICAN CONFERENCE OF GOVERNMENTAL INDUSTRIAL HYGIENISTS. Threshold limit values for chemical substances and physical agents in the workroom environment with intended changes for 1978. Cincinnati, OH 1978, p. 30.

2. BROWNE, R. C. Vanadium poisoning from gas turbines. $\mathrm{Br}$. j. ind. med. 12 (1955) 5759.

3. DIMOND, E. G., CARAVACA, J. and BENCHMOL, A. Vanadium, excretion, toxicity, lipid effect in man. Am. j. clin. nutr. 12 (1963) 49-53.

4. HEYDORN, K. and LUKENS, H. R. Preirradiation separation for the determination of vanadium in blood serum by reactor neutron activation analysis (RISO report no. 138). U.S. Atomic Energy Commission, Risoe 1966. $20 \mathrm{p}$.

5. JARACZEWSKA, W. and JAKUBOWSKI, M. Preliminary evaluation of exposure to vanadium dust in chemical industry. In: XIV International Congress on Occupational Health, Madrid 1963.

6. KENT, N. L. and MC CANCE, R. A. The absorption and excretion of minor elements by man: Silver, gold, lithium boron and vanadium. Biochem. $j$. 35 (1941) 837-844.

7. KIVILUOTO, M., RÄSÄNEN, O., RINNE, 
A. and RISSANEN, M. Effects of vanadium on the upper respiratory tract of workers in a vanadium factory. Scand. j. work environ. \& health 5 (1979) $50-58$.

8. NATIONAL INSTITUTE FOR OCCUPATIONAL SAFETY AND HEALTH. Criteria for a recommended standard... Occupational exposure to vanadium (NIOSH publication no. 77-222). U.S. Department of Health, Education and Welfare, Washington, DC 1977, $142 \mathrm{p}$.

9. NATIONAL RESEARCH COUNCIL (Committee on Biological Effects of Atmospheric Pollutants). Vanadium. Washington, D. C. 1974, pp. 46-70.

10. OHMAN, H. and ODELYCKE, P. Provtagnings- och analysförfaranden för silikosfarligt damm (AI-rapport no. 3). Arbetsmedicinska Institutet, Stockholm 1968, p. 20.

11. PERRY, J. M. JR. and PERRY, E. F. Normal concentrations of some trace metals in human urine: Changes produced by ethylenediaminetetra-acetate. J. clin. invest. 38 (1959) 1452-1463.

12. ROSHCHIN, A. V. and ORDJONIKIDZE, E. K. Absorption, distribution and excretion of vanadium from animal organism. In: XIX International Congress on Occupational Health, Dubrovnik, 1978, pp. 121122.
13. SJÖBERG, S.-G. Vanadium pentoxide dust: A clinical and experimental investigation on its effects after inhalation. Acta med. scand. 138 (1950): suppl. 238, 1-188.

14. SJÖBERG, S.-G. Vanadium dust, chronic bronchitis and possible risk of emphysema: A follow-up investigation of workers at a vanadium factory. Acta med. scand. 154 (1956) $381-386$.

15. SUOMEN STANDARDISOIMISLIITTO. Measurement of dust concentration in workplace air with filter method. (SFS 3860). Helsinki 1976, 6 p.

16. TOSSAVAINEN, A. and KOKKO, A. Precision and accuracy of foundry dust exposure estimates from air sampling data. Scand. j. work environ. \& health 2 (1976): suppl. 1, 13-18.

17. VINTINNER, F. J., VALLENAS, R., CARLIN, C. E., WEISS, R., MACHER, C. and OCHOA, R. Study of the health of workers employed in mining and processing of vanadium ore. Arch. ind. health 12 (1955) $635-642$.

18. WATANABE, H., MURAYAMA, H. and YAMAOKA, S. Some clinical findings on vanadium workers. Jpn. j. ind. health 8 (1966) 23-27.

19. WILLIAMS, N. Vanadium poisoning from cleaning oilfired boilers. $B r$. j. ind. med. 9 (1952) $50-55$. 